Agro-Science Journal of Tropical Agriculture, Food, Environment and Extension Volume 18 Number 2 (May 2019) pp. 42-50

ISSN 1119-7455

\title{
A SYSTEMATIC REVIEW OF THE IMPACT OF GHANA'S SCHOOL FEEDING PROGRAMME ON EDUCATIONAL AND NUTRITIONAL OUTCOMES
}

\author{
Awojobi O.N. \\ Department of Research and Policy National Youth Council of Nigeria, \\ Lagos State Chapter 50, Akinwunmi Street, Alagomeji, Yaba, Lagos, Nigeria. \\ Corresponding author's email: dawojobi@gmail.com
}

\begin{abstract}
The Ghana School Feeding Programme (SFP) was introduced in 2005 to improve educational and health outcomes. Due to the role the intervention has played in meeting its objectives, the review was conceived to assess the impact of the intervention on anthropometric, behavioural, cognitive, and health and nutritional outcomes. A systematic review search for non-experimental and quasi-experimental studies was conducted on different databases, websites and reference lists of selected studies. Both quantitative and qualitative studies were included in the review. Sixteen studies met the inclusion criteria and they report on the role of Ghanaian's school feeding programme as an intervention that the government is using to improve educational and health outcomes of beneficiaries. Different evaluation methods were used to assess the impact of SFP, six studies used post study design, only one study adopted Difference-inDifferences(DID)technique, five studies used a pre-post study, two studies embraced a cross-sectional study and one study adopted comparative analysis. Outcomes measured by the studies include enrolment, attendance, retention and academic performance. Others are wasting, thinness and stunting. Supporting evidence shows that the school feeding programme improved educational and health outcomes. However, the evidence of food for education on cognitive development was weak. Food for education is a social safety net that stakeholders in developing countries are using to encourage pupil enrolment, attendance and the improvement of academic performance. While the intervention played a pivotal role in these regards, there were other challenges that affected the intervention in achieving its main objective.
\end{abstract}

Key words: attendance, enrolment, Ghana, retention.

\section{INTRODUCTION}

The focus by most African nations on universal primary education has prompted the sudden improvement in primary school enrolment rate. However, school attendance rate remains low because school-age children from poor families are often needed to work in the farms or look after their younger siblings while their parents are at work. Furthermore, poor health and short-term hunger allow children to skip school as pupils who are hungry during school hours cannot learn effectively (Adelman et al., 2008). School Feeding Programmes (SFPs) which consist of meals served to pupils in schools, as well as take-home rations subjected to a pupil's school attendance, are a common way of enhancing school participation and also promoting learning and complementing the insufficient diets of school-age children. These school meals have the possibility of reducing shortterm hunger and aid pupils' concentration to learn. The meal is frequently fortified to tackle the nutritional deficiencies and enhance health and cognitive functioning (Adelman et al., 2008). A School Feeding Programme (SFP) is a social safety net that aims to improve the educational and health outcomes of school pupils. Some studies have argued that SFP can increase enrolment, attendance rates as well as test scores among pupils (Ahmed, 2004; Mohamed, 2015; Nyarko, 2014). Furthermore, the nutritional value of the school meal impacts the health status of school pupils positively (Adelman et al., 2008; Gelli et al., 2016). The positive impact associated with SFP has made most of the African nations to introduce the programme in most of their primary schools. The World Food Programme (WFP) estimated that in 2013 there were 30 million children receiving school meals in Sub-Saharan Africa (WFP, 2013). In Ghana, the implementation of the school feeding programme started in 2005 and the main objectives include: (i) increasing school enrolment, attendance and retention and (ii) decreasing hunger and malnutrition. There have been claims and counterclaims of the impact of the school feeding programme in Ghana. This study was therefore initiated to systematically review the impact of SFP and it adopts a systematic mixed-methods analysis. The rest of the study consists of the methodology adopted, results, discussion and conclusion. 


\section{MATERIAL AND METHODS}

The Approach to a Systematic Review

A systematic review is a literature review that attempts to identify, assess, select and synthesize evidence important to a research question (Lawson, 2012). This method has been used in different disciplines and often use various terminologies to explain the review process (Berrang-Ford et al., 2015). The terminology, systematic review was initially coined within the social sciences, however, it is commonly used in recent literature to refer to formal, strictly standardised review papers (Berrang-Ford et al., 2015). There are different approaches of conducting a systematic review, but four key requirements are predominant across review: a) defining the problem, inclusion and exclusion criteria; b) search strategy; c) criteria for the assessment of literature; and d) data collection (Lawson, 2012). This study employs the four key requirements mentioned above while some other features of a systematic review process were excluded. For instance, a quantitative meta-analysis technique was not included in the study.

\section{Search Strategy}

The collection of relevant literature for this study was done electronically. The search was conducted on Google search engine with "the impact of School Feeding Programme in Ghana" and "school feeding programmes in Ghana and health outcomes" titles for existing literature. Further electronic search for school feeding programme literature was conducted using Google Scholar. This helped in identifying major sources of data that encompassed studies from the World Food Programme (WFP) Reports, online websites of the WFP and Food and Agricultural Organization (FAO) and Conference/Discussion/Working Papers. Furthermore, graduate school theses from the University of Cape Coast and the University of Ghana formed part of the data of this study.

\section{Inclusion and Exclusion Criteria}

Peer review research journals on educational and health outcomes of SFPs were considered for the study. Both qualitative and quantitative studies were included in the review. Qualitative studies that assessed the impact of SFPs through research participants were also included. Grey literature, reports, policy documents and online documents that assessed the impact of Ghana's SFPs were excluded from the study. For studies to be included, they must report one of the primary outcomes, inter alia enrolment, attendance, test score, dropout/retention and academic performance. The secondary outcomes include the impact of SFPs on health benefits.

\section{Data Extraction}

Data from each of the included research journals were recorded in a data collection form. For each of the study, relevant information that includes citations, study location, intervention, sample size, evaluation design, methods of evaluation, methods and study outcomes measured were extracted. The impacts of these studies on behavioural outcomes were graded as (i) positive correlation (ii) negative correlation and (iii) not statistically significant. The findings of the included studies were used to judge their impacts on the behavioural outcomes.

\section{Data Analysis \\ A systematic procedure was followed to extract vital information. Data gathered from the systematic review process were analysed by section, coding and content review analysis.}

\section{RESULTS}

Study Selection

From the first electronic search for research articles based on titles, 100 articles were identified out of which 40 were duplicates and excluded. Sixty articles were retained after the exclusion of duplicated articles. After the screening of titles and abstracts of the 60 articles, 39 of them were excluded. The remaining 21 articles were screened by full-text for eligibility and only 5 articles did not meet the eligibility criteria. A total of 16 articles met the study eligibility and were included in the study. (See Figure 1 for the study search flow diagram).

\section{Characteristics of Included Studies}

After a rigorous screening of search research articles, a total of 16 articles were included in the study. Most of the studies were carried out in different locations in Ghana. The data samples include primary school pupils, schools, teachers and stakeholders. The methodology employed by most studies includes 4 quantitative and 12 mixedmethods. In terms of evaluation design, 13 studies used non-experimentally controlled and 3 adopted quasi-experimental design. Different evaluation methods were used to assess the impact of SFP. Six studies used post study design, only one study adopted DID, 5 studies used a pre-post study, 2 studies embraced a cross-sectional study and one study adopted comparative analysis. The intervention that was assessed by the 16 included studies was school meals, and the types of outcomes measured by these studies include enrolment, attendance, retention/drop-out and test score. Others are nutrient, stunting, thin and weight. Table 1 presents a detailed summary of the characteristics of the included studies. The impact of Ghana SFPs is divided into educational and health outcomes. 


\section{Impact on Anthropometric Outcomes}

Healthy nutrition is essential for the growth and development of people, the lack of good nutrient in people exposed them to health complications (Kwabla et al., 2018). In developing countries, the issue of child malnutrition is of great concern (Agbozo et al., 2017; Kwabla et al., 2018). Because of this, the Ghanaian government, in 2005, launched the School Feeding Programme as a social safety net to reduce child malnutrition. Measuring the growth of children is a crucial indicator of the health and nutritional status of people (WHO, 2010). Anthropometric measurements are used to quantify nutritional status, especially stunting, wasting (thin) and underweight (Lawson, 2012). Differences in anthropometry as a result of SFPs can be associated with two physical growth indicators: weight and height increase owing to increased caloric intake (Lawson, 2012). Improving the nutritional absorption of children significantly boosts growth, supports enhanced muscle mass, and enhances immunity to diseases that may upset growth (Adelman et al., 2008). Of the 16 studies of this systematic review, only two measured anthropometric outcomes (Agbozoet al., 2017; Kwabla et al., 2018). Table 2 shows the two studies reporting anthropometric measurements. In the Hohoe municipality, the differences between the treatment and control schools in underweight, stunting, thin and overweight observed were not statistically significant (Agbozo et al., 2017). The treatment schools had underweight $12.4 \%$ and stunting $13.3 \%$ as against the control schools of $16.8 \%$ and $8.6 \%$, respectively (Agbozo et al., 2017). More to this, the control schools were observed to have significantly high mean heightfor-age $\mathrm{z}$-score compared to the treatment school (Agbozo et al., 2017). A significant number of underweight children were found in rural schools $(16.5 \%)$ as against urban schools (13.5\%) (Agbozo et al., 2017). Thinness, overweight and stunting were the anthropometric indicators used by Kwabla et al. (2018) to measure child malnutrition in the Denkyembour district. The findings from the study revealed that for all respondents, $6.7 \%$ were thin, $0.8 \%$ was overweight and $16.7 \%$ were stunted while $0.6 \%$ was well nourished (Kwabla et al., 2018). The study analysis shows that stunting was common in the control schools (17.2\%) than the treatment schools $(16.2 \%)$ with no significant difference. For thinness, the children in the treatment schools had $9.3 \%$ as compared to children in the control schools $(4.6 \%)$. Only $1.9 \%$ of children in the treatment school were found to be overweight while no overweight was found in the control schools.

\section{Impact on Behavioural Outcomes}

One of the main objectives of the GSFP is to increase primary school enrolment, attendance and retain school pupils (Odame, 2014). Therefore, SFPs are hypothesised to modify schooling decision for households who would not have sent their children to school (Adelman et al., 2008). This behavioural change by parents and their children is manifested in the levels of increase in such results as enrolment, attendance and retention (Lawson, 2012). Among the 16 sample studies of this review, 13 reported the positive impact of GSFP on behavioural outcomes (Aliu and Fawzia, 2014; Gyasi et al., 2018; Konzabre, 2018; Kudus, 2011; Mahama, 2017; Milledzi et al., 2017; Nyarko, 2014; Odame, 2014; Oduro-Ofori and Adwoa-Yeboah, 2014; Osei-Fosu, 2011; Serebour, 2017; Tagoe, 2018; Yendaw and Dayour, 2015). School enrolment increases due to SFP have been reported in 13 studies while 12 studies each reported the positive impact of SFP on attendance and retention (Table 3). In the Tamale metropolis, one hot nutritious meal per day contributed to an increase in enrolment, attendance and retention (Aliu and Fawzia, 2014). However, there are other factors that also contributed to school enrolment, attendance and retention. In the Savelugu/Nantong, South Tongu, districts and WA municipality, aside from the increase in enrolment, attendance and retention, SFPs also led to girls having access to education and the reduction in the incidence of sexual activities among them (Kudus, 2011; Mahama, 2017; Milledzi et al., 2017; Oduro-Ofori and Adwoa-Yeboah, 2014).

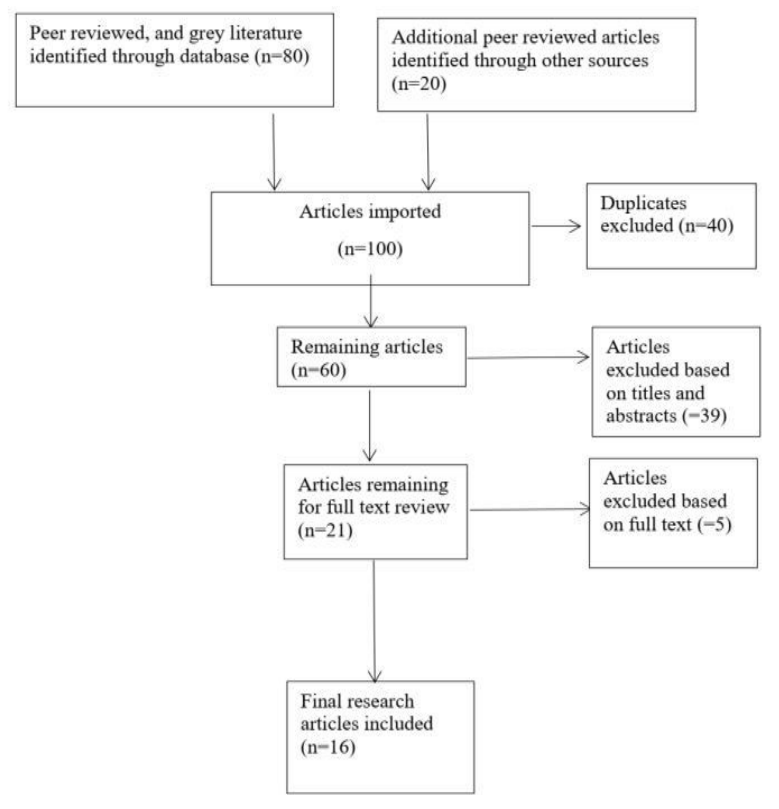

1 Figure 1: Flow diagram showing study selection for systematic review on SFP in Ghana 


\begin{tabular}{|c|c|c|c|c|c|c|c|}
\hline Study & Location & Treatment & Data Sample & Design of impact evaluation & $\begin{array}{l}\text { Methods of impact } \\
\text { evaluation }\end{array}$ & Methods & Outcomes measured \\
\hline Aliu and Fawzia, & Tamale metropolis & SPF & 4 Schools, 98 respondents & Non-experimental & Post study & Mixed & $\mathrm{B}, \mathrm{C}, \mathrm{H} \& \mathrm{~N}$ \\
\hline \multicolumn{8}{|l|}{2014} \\
\hline Agbozo et al.2017 & Hohoe municipality & SFP & 417 pupils, 14 schools & Non-experimental & Cross-sectional & Mixed & A, H\&N \\
\hline Gyasi et al. 2018 & Bawku municipality & SFP & 120 respondents, 10 schools & Non-experimental & Post study & Mixed & $\mathrm{B}, \mathrm{C}, \mathrm{H} \& \mathrm{~N}$ \\
\hline Konzabre, 2018 & Telensi district & SFP & 40 pupils, 4 schools & Non-experimental & Pre-post & Mixed & $\mathrm{B}, \mathrm{C}, \mathrm{H} \& \mathrm{~N}$ \\
\hline Kwabla et al. 2018 & Denkyembour district & SFP & 359 pupils & Quasi-experimental & Cross-sectional & Quantitative & A \\
\hline Kudus, 2011 & Savelugu/Nanaton district & SFP & 100 respondents, 6 schools & Non-experimental & Post study & Mixed & $\mathrm{B}, \mathrm{C}$ \\
\hline Mahama, 2018 & WA municipality & SFP & 89 respondents & Non-experimental & Post Study & Mixed & $\mathrm{B}$, \\
\hline Milledzi et al. 2017 & South Tongu district & SFP & 213 respondents, 15 schools & Non-experimental & Post study & Mixed & $\mathrm{B}, \mathrm{C}$ \\
\hline Nyarko, 2014 & Abura-Asebu-Kwamankese & SFP & 80 respondents & Non-experimental & Cross-sectional & Mixed & $\mathrm{A}, \mathrm{B}, \mathrm{C}, \mathrm{H} \& \mathrm{~N}$ \\
\hline Odame, 2014 & Tema metropolis & SFP & 6 schools, class 6 pupils & Non-experimental & Pre-post & Mixed & $\mathrm{A}, \mathrm{B}, \mathrm{C}$ \\
\hline Oduro-Ofori \& & Kwaebibirim district & SFP & 94 respondents, & Non-experimental & Pre-post & Mixed & $\mathrm{B}, \mathrm{H} \& \mathrm{~N}$ \\
\hline Adwoa-Yeboah, 2014 & & & 5 schools & & & & \\
\hline Osei-Fosu, 2011 & Weweso circuit & SFP & $\begin{array}{l}10 \text { Treatment schools, } 10 \\
\text { control schools }\end{array}$ & quasi-experimental & DID* & Quantitative & A \\
\hline Study & Location & Treatment & Data Sample & Design of impact evaluation & $\begin{array}{l}\text { Methods of impact } \\
\text { evaluation }\end{array}$ & Methods & Outcomes measured ${ }^{\text {a }}$ \\
\hline Owusu et al. 2016 & $\begin{array}{l}\text { NkwatanangMadina } \\
\text { municipality }\end{array}$ & SPF & 2 schools & quasi-experimental & Pre-post & Comparative & $\mathrm{H} \& \mathrm{~N}$ \\
\hline Serebour, 2017 & $\begin{array}{l}\text { AtwimaNwbiagya and } \\
\text { AtwimaMponua districts }\end{array}$ & SFP & 33 respondents, 2 schools & Non-experimental & Cross-sectional & Mixed & B \\
\hline Tagoe, 2018 & Accra Central district & SFP & 12 respondents, 6 schools & Non-experimental & Post study & Mixed & $\mathrm{B}, \mathrm{C}$ \\
\hline $\begin{array}{l}\text { Yendawi and Dayour, } \\
2014\end{array}$ & $\begin{array}{l}\text { Savelugu-Nantong } \\
\text { municipality }\end{array}$ & SFP & 150 respondents & Non-experimental & Pre-post & Mixed & B \\
\hline
\end{tabular}

Notes: Anthropometric (A), Behavioural (B), Cognitive (C), Health and Nutrition (H\&N); *DID is Different in Different Method 
A descriptive survey design by Nyarko (2014) revealed that school meal increased enrolment, attendance and retention, however, there were some challenges that affected the implementation of the programme at the school level. Similarly, despite the positive impact of SFP on educational outcomes, fees levied on school pupils by the Parent Teacher Association (PTA) affected the impact (Osei-Fosu, 2011). In the Atwim Mponua and Atwima Nwabiagya districts, it was discovered that school meals have a positive impact on enrolment (Serebour, 2017). One of the operators of the social safety net attested to the positive impact of the intervention "....it is gratifying to note that the school feeding programme has so far gone very well. The enrolment numbers have almost doubled and the current population of the pupils we have from Primary One (1) to Primary Six (6) is even getting out of hand" (p.91)."Aside from the increase in enrolment in the two beneficiary schools, findings from the study revealed that attendance and retention were impacted positively by the social safety net. The only study that took place in the Ghanaian capital, Accra among the selected study of this review shows how little kids that are not supposed to be in school are enrolled due to the school meal "...littlekids whom you wouldn't expect to be in primary school have now come to school. They canbarely read or write but they are here. I believe their parents brought them here because of the program..., and it's simply because it never used to be the case before the introduction of the school feeding programme" (Tagoe, 2018:51).School meals attract pupils to school which improve school attendance “...because I know there is food in school, I tell my children to go to school. I'm strict in making sure they attend school. I'd rather have them in school to get food every day than to stay here with me hungry with no food" (Tagoe, 2018:53). The study also found a positive correlation between school meal and retention. The meal allows the pupils to remain in school until the completion of the primary school studies (Tagoe, 2018). Yendaw and Dayour (2015) examined the effect of SFP on pupil enrolment, attendance and retention in the Savelugu-Nantong municipality. Using pre-post impact evaluation methods, the study found that the school enrolment rate was $35.8 \%$ before the introduction of the intervention but increased to $64.2 \%$ after the intervention was implemented. As for attendance, the study found that before the intervention, the attendance rate was $22 \%$ throughout the week, while $36.7 \%$ came to school three times a week. However, when the intervention was introduced, the attendance rate jumped to $65.4 \%$. The study findings also revealed that the completion of pupils' studies improved when the intervention started. In the Telensi district, Konzabre (2018) found that SFP had an impact on basic school enrolment and retention. After the introduction of SFP, enrolment increased by 213 pupils, however, the study revealed that other confounding variables such as natural population increase, the absence of school fee payment, proximity to the school and school academic achievements also impacted the school enrolment. As for retention, the study findings assert that due to the SFP, retention increased significantly. Rice with ground soup, rice and stew, Jollof rice and other types of food provided beneficiary schools in Bawku municipality was the subject of a study by (Gyasi et al., 2018). Analysis from the pre-post study shows that enrolment and attendance increased when SFP was introduced as compared when there was not SFP. Odame (2014) analysed the impacts of the SFP on educational outcomes in the Tema municipality. The beneficiary schools experienced an increase in school enrolment and attendance from households that did not have the resources to support their school-aged children to have a basic education. Despite this, the academic performance among beneficiary pupils since the beginning of the intervention has not been consistent.

\section{Impact on Cognitive Outcomes}

Eight sample studies investigated the impact of GSFP on cognitive development of school pupils (Aliu and Fawzia, 2014; Gyasi et al., 2018; Konzabre, 2018; Kudus, 2011; Milledzi, Keney, and Amponsah, 2017; Nyarko, 2014; Odame, 2014; Tagoe, 2018) Among these sample studies, six investigated the impacts on test score/academic performance while two investigated other cognitive effects. In Tamale metropolis, Aliu and Fawzia (2014) found that test score of beneficiary people of school meal increased as well as class attentiveness. For Gyasi et al. (2018), the quality of food given to beneficiary pupils improved their academic performance. This outcome was reinforced by the findings of Milledzi et al. (2017) which revealed that the academic performance of pupils increased with the starting of the SFP.

Table 2: Impact of SFP on indicators of physical growth of children

\begin{tabular}{lllllll}
\hline Study & Age Group & Treatment & Stunting & Underweight & Wasting & Others \\
\hline Agbozo et al. 2017 & 3-12y & SFP (meal) & n.s. & n.s. & n.s. & Overweight n.s. \\
Kwabla et al. 2018 & School aged-children & SFP (meal) & $16.7 \%$ & & $6.7 \%$ & $\begin{array}{l}\text { Overweight } 0.8 \% . \\
0.6 \% \text { well nourished }\end{array}$ \\
\hline
\end{tabular}

Note: n.s. is not statistically significant 
In support of this, one of the beneficiary pupils stated "...When I eat, I become alert and able to concentrate. And when I eat, I become happy and eat; I become happy and able to focus on class activities "(Milledzi et al., 2017:112). Aside from the improvement of pass rate due to SFP, the findings by Nyarko (2014) show that the intervention positively impacted the thinking ability, understanding and concentration of pupils in the class. According to one of the teachers of the pupils ... children can now think effectively in my class during lessons... (p.9) due to social intervention. Odame (2014) examined the effect of SFP on educational achievement in the Tema municipality. The study employed a mixedmethods approach; the outcomes indicated that pupils test score improved in some beneficiary schools, however, the test score was not consistent. Similarly, Tagoe (2018) conducted a study on the impact of SFP on pupils' academic performance in the Accra central district, the outcomes of the study showed that there was a significant improvement in the academic performance of primary school pupils. The academic performance was measured by pupils transcends in the class assignment, participation and final exams. Other cognitive results were reported by (Konzabre, 2018; Kudus, 2011). While the former reported that GSFP had a positive impact on pupils' learning which translated pupils listening attentively in class as stated by a Primary Six pupils ... whenever I eat food in school, it helps me to listen attentively to my teachers. Konzabre, 2018:86). The latter findings show that GSFP promotes cognitive development due to the academic progression of beneficiaries.

\section{Impact on Health and Nutrition Outcomes}

Eight selected studies of this systematic review report on the effects of SFP on health and nutritional outcomes. Outcomes that these study measured include calories, nutrients and morbidity and illnesses. The outcomes for calories and nutrients are displayed in Table 4 and that of morbidity and illnesses in Table 5. The quality of nutritious meals given to pupils in Hohoe municipality and Tamale metropolis decreased malnutrition among pupils and improved their nutritional status (Agbozo et al., 2017; Aliu and Fawzia, 2014). In the Bawku municipality, protein from the beans meal increased the protein consumption of pupils as compared to the less carbohydrate that pupils consumed (Gyasi et al., 2018). The calorie intake by pupils between the ages of 5 to 12 years who were in Primary 1 to 6 in the Denkyembour district did not meet the requirement as stipulated by the World Food Programme (WFP) (Kwabla et al., 2018). This could have been because of the inconsistent funding of the scheme. A similar study by Owusu et al. (2016) in the Nkwatanang Madina municipality where school children were served carbohydrate, protein and vegetable, found that the school meals did not meet the macronutrient requirements that have been set by $\mathrm{WHO}$ and FAO. A study conducted by Oduro-Ofori and AdwoaYeboah (2014) at the Kwaebibirim district showed that there were mixed feelings by the beneficiaries of the school meals. Some pupils claimed they were satisfied with the meals, others felt that the meals were not nutritious and could not sustain them through the afternoon, the rest pupils claimed they did not have a well-balanced meal. A crosssectional survey by Nyarko (2014) in the AburaAsebu- Kwamankese district revealed that school meal enhanced the nutritional status of the beneficiaries to some extent but could not enhance their Body Mass Index (BMI) and height.

\section{Other Impacts}

Some sample studies reported other positive impacts emanating from the SFP. For instance, short -term hunger was mentioned to have reduced by (AliuandFawzia, 2014; Kudus, 2011; Mahama, 2017; Tagoe, 2018). SFP had an impact on reducing school drop-out rate among beneficiaries of school meals (Mahama, 2017; Oduro-Ofori and Adwoa-Yeboah, 2014; Tagoe, 2018). Households income increase due to the supply of farm products to schools participating in the GSFP and the saving culture of parents who would have given their child's school feeding money if the SFP had not been in place was reported by (AliuandFawzia, 2014; Konzabre, 2018; Kudus, 2011; Mahama, 2017; Milledzi, et al., 2017; Oduro-Ofori and Adwoa-Yeboah, 2014; Tagoe, 2018). Stakeholders in Sub-Saharan Africa are promoting girl-child education due to the many socioeconomic factors limiting the girl-child education.SFP is one social invention that has been used to encourage girls' enrolment in schools and it has been reported to have a positive impact girls' enrolment (Konzabre, 2018; Kudus, 2011; Mahama, 2017). While Mahama (2017) reported that the SFP has decreased the incidence of sexual escapade and early child marriage among girls due to their continued stay in school, the study concluded that teenage pregnancy was the leading factor in the girls' school dropout in Ghana.

\section{Adverse Impact of SFP}

Around four sample studies report the negative effects of the GSFP (AliuandFawzia, 2014; Milledzi et al., 2017; Oduro-Ofori and AdwoaYeboah, 2014; Tagoe, 2018). In the Tamale metropolis, the impact of SFP on pupil enrolment has led to an increase in class size which affected the availability of teaching and learning materials (AliuandFawzia, 2014). The increase in enrolment in the South Tongu district increased the workload 
of teachers and the teacher-pupil ratio as well as children running away from school after eating (Milledzi et al., 2017). Aside from the stomach upset that pupils encountered due to the frequent eating of 'garri' and beans, the increase in class size increased the teachers' workload by $30 \%$ in the Kwaebibirim District (Oduro-Ofori and Adwoa-Yeboah, 2014). In Accra Central district, due to the meal being served to school children, it disrupts class activities as stated by one of the teachers "... because of the school feeding program, children do not spend all full school hours on school. They also spend most of the time in queue for food and that they come back to class very late. This sometimes distracts teachers from finishing lessons on time" (Tagoe, 2018:56).

\section{DISCUSSION}

A school feeding program is a social safety net that is meant to support vulnerable children in developing countries to attract them to school. Evidence has shown that when school meal is served in school, it increases enrolment, attendance and leads to retention. There is also the notion that a school feeding programme improves the academic performance of pupils as well as reducing the dropout rate among beneficiaries. Current literature on school feeding programmes in Africa has expatiated on the impact of school meal to beneficiaries. For instance, a study on the evaluation of school meal on educational achievement in Sub-Saharan Africa, using a randomised control trial, the study found that net enrolment at the kindergarten level increase by nearly eleven per cent and there was an improvement in learning achievement, attention and cognition (Adamba et al., 2008). Similar findings of the systematic review aligned with that of Adamba et al. (2008) on the impact of school meal on enrolment. The results of the systematic review of this study indicated that there has been a dramatic increase in the school enrolment of the beneficiary schools in districts where SFP is in practice. There is a pathway through which SFP may impact pupils educational and health outcomes. SFP increases school enrolment and attendance rates as well as enhance learning and educational outcome, which may be boosted by enhanced nutrition and cognitive function (Adelman et al., 2008). Empirical evidence has shown that school meal attracts children to school thereby increasing school enrolment. Thirteen of sample studies reviewed in this study supported this claim from their empirical findings. SFP can also be an effective way of increasing school attendance rate because pupils receive the meal only when they are present in school (Adelman et al., 2008). In addition, through improved nutrition status school attendance may be improved. For instance, a school meal can reduce a pupil's shortterm hunger during school hour, by providing extra nutrients to the pupil. Also, the more nutrient a child gets through SFP could enhance the child's physiological ability to learn, which has an immediate effect on the advantages of schooling and an implicit effect of intensifying the child's aspiration to attend school. Furthermore, school meal may enhance attendance through nutrition by decreasing illnesses. It is argued that illness among children is a major cause of absenteeism in schools in developing countries (Adelman et al., 2008). Enriched nutrition, particularly sufficient consumption of micronutrients, can fortify the immune system and decrease the prevalence and gravity of infectious diseases among children (Scrimshaw and SanGiovanni, 1997). Hence, if school meals enhance children's nutritional status, they may decrease illness and reduce the number of days the children will absent themselves from school due to illness, therefore, increasing attendance (Adelman et al., 2008). SFP can decrease short-term hunger and micronutrient deficiencies, which can rise cognitive function and resistance to intestinal and respiratory infections (Jamison et al., 2006). School meal can lead to increase in cognition and learning. For example, the WFP data revealed that an additional year of SFP leads to a rise in cognition of 0.09 SD in test scores in Lao People's Democratic Republic (PDR) (Molinasand de la Mothe, 2010). Despite the positive impact of SFP, there have been some shortcomings on its operation. For instance, policy makers and donors argue that these programmes are a costly approach to producing the stated education and nutrition goals and that other more economical procedures exist (Adelman et al., 2008). Another general setback of SFP is that it usually fails in implementation due to unpredictable food availability or unorganised meals that interrupt academic activity (Adelman et al., 2008).

Table 3: Impact of SFP on behavioural outcomes

\begin{tabular}{llll}
\hline Study & Enrolment & Attendance & Retention \\
\hline Aliu and Fawzia, 2014 & $\uparrow$ & $\uparrow$ & $\uparrow$ \\
Gyasi et al. 2018 & $\uparrow$ & $\uparrow$ & \\
Konzabre, 2018 & $\uparrow$ & & $\uparrow$ \\
Kudus, 2011 & $\uparrow$ & $\uparrow$ & $\uparrow$ \\
Mahama, 2018 & $\uparrow$ & $\uparrow$ & $\uparrow$ \\
Milledzi et al. 2017 & $\uparrow$ & $\uparrow$ & $\uparrow$ \\
Nyarko, 2014 & $\uparrow$ & $\uparrow$ & $\uparrow$ \\
Odame, 2014 & $\uparrow$ & $\uparrow$ & \\
Oduro-Ofori and & $\uparrow$ & $\uparrow$ & $\uparrow$ \\
Adwoa-Yeboah, 2014 & $\uparrow$ & $\uparrow$ & $\uparrow$ \\
Osei-Fosu, 2011 & $\uparrow$ & $\uparrow$ & $\uparrow$ \\
Serebour, 2017 & $\uparrow$ & $\uparrow$ & $\uparrow$ \\
Tagoe, 2018 & $\uparrow$ & $\uparrow$ & $\uparrow$ \\
Yendawi and Dayour, & $\uparrow$ & $\uparrow$ & \\
2014 & & & \\
\hline \multicolumn{2}{c}{ Note: Positives correlation $\uparrow$} & Negative correlation $\downarrow$ Not \\
statistically significant $\leftrightarrow$ & &
\end{tabular}


Table 4: Impact of SFP on health and nutrition outcomes

\begin{tabular}{|c|c|c|c|c|}
\hline Study & Age Group & Treatment & Calories & Nutrients \\
\hline $\begin{array}{l}\text { Aliu and Fawzia, } \\
2014\end{array}$ & $\begin{array}{l}\text { Primary school } \\
\text { aged children }\end{array}$ & SFP (meal) & & Malnutrition decreased \\
\hline $\begin{array}{l}\text { Agbozo et al., } \\
2017\end{array}$ & $3-12 y$ & SFP (meal) & & $\begin{array}{l}\text { Better nutritional status of pupils } \\
\text { observed. Malnutrition prevalence } \\
\text { was lower among beneficiaries }\end{array}$ \\
\hline $\begin{array}{l}\text { Gyasi et al., } \\
2018\end{array}$ & $11-15 y$ & $\begin{array}{l}\text { SFP (Beans, rice and } \\
\text { stew, rice ball and } \\
\text { ground soup, Jollof) }\end{array}$ & & $\begin{array}{l}\text { More protein given to pupils than } \\
\text { Carbohydrate }\end{array}$ \\
\hline $\begin{array}{l}\text { Kwabla et al., } \\
2018\end{array}$ & $5-12 y$ & SFP (meal) & $\begin{array}{l}\text { Food being served found not to meet the } \\
\text { recommended energy from macronutrient } \\
\text { intake as set by World Food Programme }\end{array}$ & \\
\hline Nyarko, 2014 & $\begin{array}{l}\text { Primary school } \\
\text { aged children }\end{array}$ & & & $\begin{array}{l}\text { Nutritional status improved but } \\
\text { could enhance BMI and height }\end{array}$ \\
\hline $\begin{array}{l}\text { Oduro-Ofori and } \\
\text { Adwoa-Yeboah, } 2014\end{array}$ & $\begin{array}{l}\text { School aged } \\
\text { children }\end{array}$ & SFP (meal) & & $\begin{array}{l}\text { Sometimes the meal is not a } \\
\text { balanced diet }\end{array}$ \\
\hline Owusu et al., 2016 & $5-12 y$ & SFP (meal) & $\begin{array}{l}\text { GSFP meals did not meet any of the } \\
\text { energy and macronutrient requirements } \\
\text { that have been set by WHO and FAO }\end{array}$ & Low protein \\
\hline
\end{tabular}

Table 5: Impact of SFP on morbidity and illnesses

\begin{tabular}{llll}
\hline Study & Age Group & Treatment & Morbidity \& Illnesses \\
\hline $\begin{array}{l}\text { Oduro-Ofori and } \\
\text { Adwoa-Yeboah, 2014 }\end{array}$ & $\begin{array}{l}\text { School aged } \\
\text { children }\end{array}$ & SFP (Meal) & $\begin{array}{l}\text { The pupils who reported that they have had complications from eating some types } \\
\text { of food, made mention that frequent eating of garri and beans gives them diarrhoea }\end{array}$ \\
\hline
\end{tabular}

\section{CONCLUSION}

Food for education is a social safety net that stakeholders in developing countries are using to encourage pupil enrolment, attendance and the improvement of academic performance. This systematic review looks at the role of the Ghana School Feeding Programme on educational and health outcomes. Evidence from the systematic review reveals the impact of SFP on school enrolment, attendance and test score/academic performance. While most of the reviewed studies acknowledged the positive role of SFP on educational outcomes, there are also confounding variables that support these outcomes, especially on enrolment and attendance. The systematic review revealed mixed outcomes for health outcomes. While some studies revealed that school meal increased beneficiaries' nutritional status, some food nutrients did not meet up to the standard requirements for child development. The consistent feeding of children with garri and beans in one of the beneficiary schools led to the health complications that made some children complained of stomach upset. On the anthropometric measurement of stunting, wasting, underweight and overweight vis-à-vis physical growth, there was no significant difference between treatment and control schools. The impact of SFP on cognitive development was not that all clear because most of the studies reviewed did not use administrative data to investigate the correlation between school meals and cognitive development in pre-post research design. However, SFP was considered by most studies as a factor that enhanced pupils' academic performance. The findings from the systematic review reveal the impact of SFP on educational and health outcomes in Ghana. While most of the reviewed studies acknowledged the role of school meal in school enrolment, attendance, retention, academic performance and the nutritional status of beneficiaries, there is the need for further research with the use of a randomised control trial to validate the positive impact of SFP on educational and health outcomes.

\section{ACKNOWLEDGEMENT}

The work was supported by the National Youth Council of Nigeria, Lagos State Chapter.

\section{REFERENCES}

Adamba C., Aurino E., Asante F., Kwasabem B., Gelli A., Drake L. and Osei-Akoto I. (n.d.). Evaluation of alternative school feeding models on education, nutrition, and agriculture in Ghana: Preliminary findings from a cluster randomised control trial. Retrieved from http://anh-academy.org/sites/default/ files/3.\%20 Clement.pdf (accessed 13.10.2018).

Adelman S., Gilligan D. and Lehrer K. (2008). How effective are food for education programs?: a critical assessment of the evidence from developing countries. Washington, D.C: International Food Policy Research Institute, p. 69

Agbozo F., Atitto P. and Abubakari A. (2017). Nutritional status of pupils attending public schools with and without school feeding programme in Hohoe Municipality, Ghana. Journal of Food and Nutrition Research, 5 (7), 467-474. https://doi.org/10.12691/jfnr-5-7-3

Ahmed A.U. (2004). Impact of feeding children in school: Evidence from Bangladesh. Washington, DC: International Food Policy Research Institute. Retrieved from http://www.lcgbangladesh.org/FSN/ reports/IFPRI\%20Final\%20Report_School\%20Feedi ng\%20in\%20Bangladesh.pdf (accessed 13.10.2018).

Aliu M. and Fawzia S. (2014). Assessing Ghana school feeding programme on the enrollment of beneficiary schools in the Tamale Metropolitan Assembly of Northern Ghana. International Journal of Economics, Commerce and Management, 2 (10), 1-30 
Berrang-Ford L., Pearce T. and Ford J.D. (2015). Systematic review approaches for climate change adaptation research. Regional Environmental Change, 15 (5), 755-769. https://doi.org/10.1007/s10113014-0708-7

Gelli A., Masset E., Folson G., Kusi A., Arhinful D.K., Asante F. and Drake L. (2016). Evaluation of alternative school feeding models on nutrition, education, agriculture and other social outcomes in Ghana: rationale, randomised design and baseline data. $\quad$ Trials, $17 \quad$ (1), $17-37$. https://doi.org/10.1186/s13063-015-1116-0

Gyasi G.E.O., Asante, M.M.N., Adans J. and AntwiBoasiako S. (2018). Assessing food quality delivery in the school feeding programme and its impacts on enrolment: a study of some public basic schools in Bawku Municipality of Ghana. Saudi Journal of Business and Management Studies, 3, 98-106. https://doi.org/10.21276/sjbms.2018.3.1.13

Jamison D.T., Breman J.G., Measham A.R., Alleyne G., Claeson M., Evans D.B. and Musgrove P. (Eds.). (2006). Disease Control Priorities in Developing Countries (2nd ed.).Washington (DC): World Bank. Retrieved from http://www.ncbi.nlm.nih.gov/books/ NBK11728/ (accessed 13.10.2018).

Konzabre J.G. (2018). The impact of Ghana's school feeding programme on enrollment and retention of pupils in Talensi District in Upper East Region. International Journal of Education, 6 (6), 69-89

Kudus M.A. (2011). Evaluation of the School Feeding Programme and Pupils Academic Performance in Ghana: A Study of the Catholic Relief Service Feeding Programme in Savelugu/Nanton District. University of Cape Coast, Ghana. Retrieved from https://erl.ucc.edu.gh/jspui/bitstream/123456789/110 4/1/ABDUL\%20\%E2\%80\%93\%20KUDUS\%20201 1.pdf (accessed 13.10.2018).

Kwabla M.P., Gyan C. and Zotor F. (2018). Nutritional status of in-school children and its associated factors in Denkyembour District, eastern region, Ghana: comparing schools with feeding and non-school feeding policies. Nutrition Journal, 17 (1). https://doi.org/10.1186/s12937-018-0321-6

Lawson T.M. (2012). Impact of School Feeding Programs on Educational, Nutritional, and Agricultural Development Goals: A Systematic Review of Literature. Michigan State University, Michigan. Retrieved from https://ageconsearch.umn. edu/record/142466/files/2012LawsonPlanB.pdf (accessed 13.10.2018).

Mahama S. (2017). The Impact of Ghana School Feeding Programme on Female Enrolment, Attendance and Retention in the Wa Municipality of the Upper West Region of Ghana. University for Development Studies, Ghana. Retrieved from http://udsspace.uds.edu.gh/bitstream/123456789/178 2/1/THE\%20IMPACT\%20OF\%20GHANA\%20SC HOOL\%20FEEDING\%20PROGRAMME\%20ON.p df (accessed 13.10.2018).

Milledzi E.Y., Keney G. and Amponsah M.O. (2017). Impact of school feeding programme on access to basic education: the case of South Tongu District of the Volta Region, Ghana. International Journal of Education, 9 (4), 103-117. https://doi.org/10.5296/ ije.v9i4.12124

Mohamed A.O. (2015). Influence of feeding programs on the participation of learners at early childhood development education institutions: A case of Bungoma South district. International Academic Journal of Social Sciences \& Education, 1 (4), 1-14
Molinas L. and de la Mothe M.R. (2010). The multiple impacts of school feeding: a new approach for reaching sustainability. Omamo, Gentilini and Sandström (Eds), 217-30

Nyarko S.H. (2014). Assessment of the school feeding programme in Ghana: A study of primary schools in the Abura-Asebu-Kwamankese district in the Central region of Ghana. International Journal of Research in Social Sciences, 4 (2), 1-15

Odame L. (2014). School Feeding Programme and Educational Outcome in Tema Municipality. University of Ghana, Legon. Retrieved from http://ugspace.ug.edu.gh/bitstream/handle/12345678 9/7323/Laudina\%20Odame $\% 20 \% 20$ School $\% 20$ Fee ding $\% 20$ Programme $\% 20$ and $\% 20$ Educational $\% 20 \mathrm{Ou}$ tcome\%20in\%20Tema\%20Municipality_2014.pdf;s equence $=1$ (accessed 13.10.2018).

Oduro-Ofori E. and Adwoa-Yeboah G. (2014). The contribution of the Ghana schools feeding programme to basic school participation: a study of selected schools in the Kwaebibirim District of Ghana location. Developing Country Studies, 4 (19), 40-50

Osei-Fosu A. (2011). Evaluating the impact of the capitation grant and the school feeding programme on enrollment, attendance and retention in schools: The case of Weweso circuit. Journal of Science and Technology (Ghana), 31(1), 5-64. https://doi.org/10.4314/just.v31i1.64886

Owusu J., Colecraft E., Aryeetey R., Vaccaro J. and Huffman F. (2016). Comparison of two school feeding programmes in Ghana, West Africa. International Journal of Child Health and Nutrition, 5 (2), 56-62. https://doi.org/10.6000/1929-4247.2016.05.02.2

Scrimshaw N.S. and SanGiovanni J.P. (1997). Synergism of nutrition, infection, and immunity: an overview. The American Journal of Clinical Nutrition, 66 (2), 464S-477S

Serebour R. (2017). Assessing the Implementation of the Ghana School Feeding Programme (GSFP): A Comparative Case Study of Some Selected Schools in the Atwima Nwbiagya District and Atwima Mропиа District of Ghana. University of Bergen, Norway. Retrieved fromhttp://bora.uib.no/bitstream/ handle/1956/17422/Rosemond-s-thesis.pdf?seque nce $=1$ and is Allowed=y (accessed 13.10.2018).

Tagoe I. (2018). The Ghana National School Feeding Program: Peoples' Perceptions about the Program's Impact on School Enrolment, Attendance and Completion. Bowling Green State University, United States. Retrieved from https://etd.ohiolink. edu/!etd.send_file?accession=bgsu 15216828692982 46\&disposition=inline (accessed 13.10.2018).

WFP (2013). State of School Feeding Worldwide. World Food Programme. Retrieved from https://documents.wfp.org/stellent/groups/public/doc uments/communications/wfp257481.pdf?_ga=2.213 196752.57135622 .1539805500 1078240093.1539805500 (accessed 13.10.2018).

WHO. (2010). Nutrition Landscape Information System (NLIS) Country Profile Indicators. World Health Organization. Retrieved from http://www.who.int/nutrition/nlis_interpretation_gui de.pdf (accessed 13.10.2018)

Yendaw E. and Dayour F. (2015). Effect of the national school feeding programme on pupils' enrolment, attendance and retention: a case study of Nyoglo of the Savelugu-Nantong Municipality, Ghana. British Journal of Education, Society \& Behavioural Science, $\quad 5 \quad$ (3), 341-353. https://doi.org/10.9734/BJESBS/2015/14271 